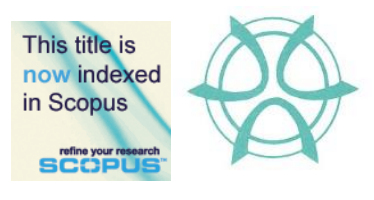

PLANNING MALAYSIA:

Journal of the Malaysian Institute of Planners

VOLUME 16 ISSUE 4 (2018), Page 155 - 160

\title{
CARRYING CAPACITY OF TOURISM DEVELOPMENT IN CAMERON HIGHLANDS, MALAYSIA
}

\author{
Diana Mohamad $^{1}$ \& Azizan Marzuki ${ }^{2}$ \\ ${ }^{1 \& 2}$ School of Housing, Building and Planning \\ UNIVERSITI SAINS MALAYSIA
}

\section{RESEARCH NOTES}

\section{TOURISM DEVELOPMENT IN CAMERON HIGHLANDS}

In the beginning, tourism existed as travelling for gathering and festival by noblemen and salvation by pilgrims. Of late, tourism generally liaises with education, business and entertainment. Given that tourism is impressive in size and pervasive in society, it is utilized as a mechanism for economic development especially by the developing countries. This paper updates the current tourism situation in Cameron Highlands $(\mathrm{CH})$ and it is within this paper interest to bring forward the consideration to prolong $\mathrm{CH}$ as one of Malaysia's top tourism destinations.

High popularity in addition to economic growth demand has stimulated rapid development to the highlands, and $\mathrm{CH}$ is no exception (Kumaran \& Ainuddin, 2006, cited in Chan, 2006). Named after William Cameron (a British surveyor), $\mathrm{CH}$ is a pot of melting treasures including distinctive biodiversity, extraordinary tropical forest retreats and wilderness. $\mathrm{CH}$ was first enjoyed as a colonial-based hill station, which the trend then moved towards agro-tourism, ecotourism and entertainment activities. Agrotourism in $\mathrm{CH}$ began the last four decades and since, has experienced notable expansion. Rather than attracting people, agro-tourism in the beginning was to encourage the locals to participate in developing $\mathrm{CH}$ while promoting the locals' values and uniqueness (Kunasekaran, Ramachandran, Yacob, \& Shuib, 2011; Ling, Mohd Noor, Marzukhi, \& Mohamed Musthafa, 2017)). Agrotourism in CH were expanded to night market, farms, gardens, recreational parks, jungle trekking and waterfall trails; where these activities are subsets to ecotourism. In particular, both agrotourism and ecotourism serve as development catalysts, at the expense of minimum utilization of rural resources. As the entire discipline of $\mathrm{CH}$ is environmentally driven and $\mathrm{CH}$ emphasized relaxation concept, this intensifies 
Diana Mohamad \& Azizan Marzuki

Carrying Capacity of Tourism Development in Cameron Highlands, Malaysia

$\mathrm{CH}$ values and benefits in terms of life support base. Referring to Ono (2010), the soaring popularity of $\mathrm{CH}$ as favoured long-stay destination among Japanese was much influenced by the Japanese financial power and intense commoditization, in addition to $\mathrm{CH}$ competent image in hospitality and service sector. Relentless development has stimulated the inclusion of resorts and hotels element into $\mathrm{CH}$ natural landscape, with the construction was bound along the dimension of nature preservation (Othman 2011). Interestingly, Chan (2006) was in the view that CH's aggressive development was activated by the construction of highways, dams, and mining and logging activities.

While experiencing agrotourism's downturns due to the emergence of new market and limited technological development, $\mathrm{CH}$ witnessed the detrimental impact of polluted waterways combined with the extreme index of agrichemicals and sewage (Barrow, Chan, \& Masron, 2009). In the case of ecotourism, it was learned that the locals were more inclined toward securing financial stability compared to considering the consequences of $\mathrm{CH}$ 's landscape rapid transformation (Othman 2011). Besides acting as a cause to increases in daily temperature (Barrow et al., 2009), development of $\mathrm{CH}$ has also triggered landslide occurrences (Nasir \& Mohd Nasir, 2013); and this indirectly suggests active deforestation activities. The reality that $\mathrm{CH}$ was struck off with unsustainable farming, massive plantation activities as well as insensitively speculative built skyscrapers (Barrow, Chan, \& Masron, 2005), probably personifies economic development as intuitively negative, selfish and socially driven. Further compounding this concern is the difficulty of assessing the development progress given CH's low accessibility and mountainous landscape.

The current scenario implies $\mathrm{CH}$ is indeed in need of urgent pursuit of effective management of tourism development. The management of tourism development is a corporative process; hence, it is most effective when stakeholders' census involvement is achieved. The primary goal of tourism management is to prolong the tourism benefits enjoyed, as this is where the contextual value is strongest. Given this, tourism carrying capacity is fast becoming a key instrument in $\mathrm{CH}$ development. Carrying capacity is perceived as the threshold of acceptance and/or endurance towards undesirable impact (Diana, Mastura, \& Azizan, 2014). As CH is dominantly operated on limited resources, managing $\mathrm{CH}$ development along the carrying capacity dimension is crucial as this allows for effective utilization and management of resources.

\section{METHODOLOGY AND FINDINGS}

This paper looks into factors that could potentially slow the progress and lighten the adversity of tourism impact. As the abovementioned studies have much covered the environment aspect, this paper is designed to study the social and economic carrying capacity of $\mathrm{CH}$. The following studies were referred as the guidelines in constructing the self-administered questionnaire: accommodation 
sector (Choi \& Chu, 2001), comfortableness aspect in tourism products (Valles 2001), safety and social issues (Likaj \& Baltaci, 2008), as well as locals' participation and foreign workers (Maiese, 2003). 430 self-administered questionnaires were distributed, targeting visitors with a minimum age of 18. 410 questionnaires were successfully retrieved (amounting to $95.3 \%$ response rate). In order to capture the fundamental tourism situation in $\mathrm{CH}$, this paper employed 4-point Likert scale [1: strongly disagree (SD), 2: disagree (D), 3: agree (A) and 4: strongly agree (SA)]. Prior to the actual data collection, the reliability and validity of the data collection instrument were first tested for the purpose of ensuring the instrument was constructed to the visitors' understanding.

From social carrying capacity (SCC) results (Table 1), observation emphasized balancing between economic benefits (tourists' arrival) and money value (tourism experience, the safety issue and hospitality), as this is where tourism harmonize varying perceptions of $\mathrm{CH}$ as a premium tourism destination. Minimal locals-tourists interaction observed has asserted self-othering scenario, hence, the 'cold treatment' experienced by tourists. Such circumstances probably ignite the locals' disappointment towards devaluation of traditional customs.

Table 1: Mean values for social variables tested

\begin{tabular}{|c|c|c|}
\hline No. & Variables & Mean \\
\hline 1 & There is an increase in tourists' arrival & 2.57 \\
\hline 2 & I am welcomed by the local community & 2.48 \\
\hline 3 & My visit is contributed by similarity/comfortability in tourism identity & 2.33 \\
\hline 4 & $\begin{array}{l}\text { Increase in tourists' arrival further support the protection of the } \\
\text { traditional culture inheritance }\end{array}$ & 2.22 \\
\hline 5 & $\begin{array}{l}\text { The traditional customs and performances are authentic, and they } \\
\text { represent the living culture of the local community }\end{array}$ & 2.20 \\
\hline 6 & $\begin{array}{l}\text { The service quality is not compromised regardless of the increase in } \\
\text { tourists' arrival }\end{array}$ & 2.02 \\
\hline 7 & $\begin{array}{l}\text { The high number of tourist has negatively contributed to my safety } \\
\text { issue }\end{array}$ & 2.65 \\
\hline 8 & $\begin{array}{l}\text { Increase in tourists' arrival has contributed to a decrease in my tourism } \\
\text { experience }\end{array}$ & 2.75 \\
\hline 9 & $\begin{array}{l}\text { The tourism industry has contributed to negative changes to the } \\
\text { traditional customs and culture }\end{array}$ & 2.82 \\
\hline 10 & $\begin{array}{l}\text { I experienced cold neighborhood phenomenon due to an increase in } \\
\text { tourists' arrival }\end{array}$ & 3.55 \\
\hline 11 & I experienced low service quality during the peak season & 2.89 \\
\hline
\end{tabular}

Looking at the economic carrying capacity (ECC) results (Table 2), tourists indicated purchasing power, satisfying amenities and growing workforce as cohesive factors nullifying their moderate dissatisfaction with money value for accommodation. The primary goal of tourism is to provide life support base to the locals, as this is where the contextual value is strongest. However, results of 
Diana Mohamad \& Azizan Marzuki

Carrying Capacity of Tourism Development in Cameron Highlands, Malaysia

growing (foreign) workers appeared to be increasingly positioned as tourism benefits, and that ultimately shifts away the locals' supportiveness towards tourism sector.

Table 2: Mean values for economic variables tested

\begin{tabular}{clc}
\hline No. & \multicolumn{1}{c}{ Variables } & Mean \\
\hline 1 & There are enough hotel/chalet workers to serve the tourists & 2.46 \\
2 & Increase in tourists' arrival has contributed to an increase in real estate & 2.09 \\
3 & value & \\
4 & My visit is contributed by the accommodation price affordability & 2.25 \\
5 & The number of room is insufficient during the peak season & 2.23 \\
6 & High demand for accommodation has contributed to an increase in & 3.35 \\
& accommodation price & 2.35 \\
7 & Tourism development has created job opportunities for the young & 2.14 \\
& locals & \\
8 & Tourism development has contributed to the better management of & 2.27 \\
9 & Lourists and public amenities & 2.14 \\
10 & Satisfy with the souvenir products price & 2.19 \\
11 & Need to build more shops and stalls & 2.48 \\
12 & Tourism in this location has high potential for growth & 2.18 \\
\hline
\end{tabular}

\section{DISCUSSION AND CONCLUSION}

Viewing from SCC point of view, economically-driven tourism development is a medium to intensifying corrosion of locals' acceptance towards tourism sector. At a greater level, it is the understanding that insensitive tourism development assists the declination of social capital (characterized by trust, cooperation and social encounters; as documented by Glover \& Filep, 2015) and this obviously depicts the locals' pitiful reward when aiming for a self-sufficient community. In relation to ECC, economically-driven tourism development is a platform for pragmatic amenities management and is a vehicle for exponentially bridge the gap in the willingness to pay equation. In particular, this recognizes the relation between tourists-based tourism development and economy potential over time (see also Antonakakis, Dragouni, \& Filis, 2015) and at the same time suggests that it is imperative to grasp the tourism advantages in a timely manner. Based on this, it could be concluded that though tourism is lucrative, it unfortunately denotes negative association with social aspect; in the context of $\mathrm{CH}$. To this paper, results of SCC and ECC have given an account and the reasons for pursuing pragmatic action(s) for $\mathrm{CH}$ tourism development, in which, personifies the appointed bodies consideration towards sustainability and longevity elements.

When sustainability concept was first coined in the development framework, it was argued for development to be transparent and to be 
rationalized. It was emphasized that rationalism maintains the conceptualization of principals and that transparency acknowledges the fundamentals of empiricism. Within such 'conceptualization of principals' and 'fundamentals of empiricism' dimensions, carrying capacity blueprint is produced by working through the locals' requirements and the visitors' desires; from the tourism sector. In the case of $\mathrm{CH}$, the visitors-tourism relationship is empathy and the localstourism relationship is mathematics; yet both relationships violate the basic principle of experiential consequences. Given this, it is increasingly difficult to separate the overlapping lines of empathy (social and physical characteristics of $\mathrm{CH}$ ) and mathematics (corporate responsibility), when handling carrying capacity.

\section{ACKNOWLEDGEMENT}

The authors would like to extend their appreciation to the Long-Term Research Grant Scheme (Grant no: 304/PPBGN/650571/T121) that makes this study and paper possible.

\section{REFERENCES}

Antonakakis, N., Dragouni, M. \& Filis, G. (2015). Tourism and growth: The times they are a-changing. Annals of Tourism Research, 50, 165-169.

Barrow, C. J., Chan, N. W., \& Masron, T. (2009). Issues and challenges of sustainable agriculture in the Cameron Highlands. Malaysian Journal of Environmental Management, 10(2), 89-114.

Barrow, C. J., Chan, N. W., \& Masron, T. (2005). Sustainable development in the Cameron Highlands, Malaysia. Malaysia Journal of Environmental Management, 6, 41-57.

Choi, T. Y., \& Chu, R. (2001). Determinants of hotel guests' satisfaction and repeat patronage in the Hong Kong hotel industry. Hospitality Management, 20, $277-$ 297.

Chan, N. W. (2006). Cameron Highlands: Issues \& challenges in sustainable development. Pulau Pinang: School of Humanities, Universiti Sains Malaysia.

Diana, M., Mastura, J., \& Azizan, M. (2014). Langkawi Island, social aspect and the carrying capacity. Proceeding of the 4th International Conference on Tourism Research (4ICTR), 12, 01023. DOI: 10.1051/shsconf/20141201023

Glover, T. D., \& Filep, S. (2015). On kindness of strangers in tourism. Annals of Tourism Research, 50, 159-162.

Kunasekaran, P., Ramachandran, S., Yacob, M. R., \& Shuib, A. (2011). Development of farmer's perception scale on agro-tourism in Cameron Highland, Malaysia. World Applied Sciences Journal, 12, 10-18.

Likaj, M., \& Baltaci, C. (2008). The changes of social structure and migration in cities in Albania. ICBS 2008, 53-610.

Ling, H. L., Mohd Noor, M. H. C., Marzukhi, M. A., \& Mohamed Musthafa, S. N. A. (2017). Social impact of agro-tourism on local urban residents. Case study: Cameron Highlands, Malaysia. Planning Malaysia, 15(2), 51-66. 
Diana Mohamad \& Azizan Marzuki

Carrying Capacity of Tourism Development in Cameron Highlands, Malaysia

Maiese, M. (2003). Social structural change. Accessed September 25, 2015 at http://www.beyondintractability.org/

Nasir, Z. A., \& Mohd Nasir, N. (2013). The determinants and measurement of tourists' satisfaction towards environmental quality at tourism destination in Cameron Highlands. Proceeding of the Global Conference on Business, Economics and Social Sciences (GBSR 2013) (pp. 565-572).

Ono, M. (2010). Long-stay tourism: Elderly Japanese tourists in the Cameron Highlands, Malaysia. Senri Ethnological Studies, 76, 95-110.

Othman, J. (2011). Scenic beauty preferences of Cameron Highland Malaysia: Local versus foreign tourists. International Journal of Business and Social Science, 2(6), 248-253.

Valles, D. M. (2001). Improving the quality of tourist products. Accessed October 20, 2015 at http://ec.europa.eu/

Received: $1^{\text {st }}$ June 2018. Accepted: $1^{\text {st }}$ December 2018 